\title{
Borrowings and their Diachronic Development in Scientific and Technical Terminology of Mechanical Engineering in Albanian
}

\author{
PhD Candidate, Edita Stojani \\ Polytechnic University of Tirana, \\ Faculty of Mathematics Engineering and Physics Engineering, Centre of Foreign Language \\ frasherie@mail.com \\ Prof. As. Fatmir Vrapi \\ Polytechnic University of Tirana, \\ Faculty of Mathematics Engineering and Physics Engineering, Centre of Foreign Language \\ fatmirvrapi@yahoo.com
}

\author{
Doi:10.5901/jesr.2015.v5n2p81
}

\begin{abstract}
This article is about diachronic development of borrowings in the lexicon of mechanical engineering. We examine a range of problems related to its linguistic and terminological character. Mechanical lexicon faces various problems pertaining to linguistic construction terms, as well as form-content relationships. To highlight the dynamic development of the lexicon, its analysis has begun prior to 1945 period because this is exactly the period of crystallization of this vocabulary closely linked with external factors. In this lexicon, there are a considerable number of foreign terms borrowed from different languages like Italian, French. These borrowings have played an important role in the formation of mechanical engineering terminology and despite the creation of Albanian terms they have created their own layer of specialized lexicon.
\end{abstract}

Keywords: borrowing, terminology, mechanical engineering, Albanian Language

\section{Introduction}

The presence of borrowings in a language is a clear indication of linguistic contacts related to geographical and historical conditions of peoples whose languages have these borrowings. The process of linguistic borrowing is a common phenomenon with a universal character, and there are many works on this issue.

We will start by discussing various pieces of scholarship before delving into the borrowings in the mechanical lexicon. E. Haugen ${ }^{1}$ in his analysis of borrowings in U.S. national minority languages, classified changes related to borrowings in a number of categories which he then compared with his model. Haugen proposes to distinguish two types of borrowings: imported borrowings when the loan is similar to the model so that native speakers can accept as their own, and replaced borrowings when a speaker reproduces the foreign model in a modified way, replacing it with a form similar to his tongue. In terms of imported borrowings in foreign apparently are scarce, because rarely it happens that a borrowing does not undergo modifications. The degree of subordination of a new borrowing to the system depends first of all by the ability of the language to assimilate other terms.

Apart from the general analysis of borrowings in a given language, the study of borrowings in the field of scientific and technical terminology is becoming more frequent. The penetration rate of borrowings related to a specialized language is greater than in the general language and therefore the terminology borrowings is faster. Also, a borrowing in the technical terminology represents the concept, which facilitates identification of the borrowing travel as well as determines the source of the intermediate language. In our study of mechanics lexicon borrowings, we focus on some issues, such as, description of the method of penetration of these borrowings in Albanian, the identification of borrowings guidance and criteria that determine the source language and intermediate language, and the classification of borrowings under the relevant perspective.

\footnotetext{
${ }^{1}$ Haugen E, The analysis of linguistic borrowing:, Language 1950, pp. 211.
} 


\section{Research Methods}

Under the Albanian linguistics, borrowings are grouped in different ways. From the standpoint of involvement in FGJSSH (1980), borrowings are classified as: a) foreign words with an international character and b) foreign words, not international. ${ }^{2}$ In today's works on terminology borrowings are mainly classified in two different ways from each other. According to the first classification terminology borrowings are divided into: 1 ) international borrowings; 2) real and direct borrowing; and 3) indirect borrowings. ${ }^{3}$ In the second classification of borrowings, the author is influenced by: a) their affiliation logical-Real; b) the language of which are borrowed; c) their value and d) the extent of their acquisition of language. Borrowing terminology is characterized by certain features related to the specific nature of the term compared with the general language word.

The study of linguistic borrowings in general and in a particular terminology defines the circumstances and causes of their penetration and sheds light on the degree of their assimilation by the Albanian language. In this context we will focus mainly on the introduction of borrowings in the field of mechanics in Albanian, and will try to structure the way these borrowing penetrate in the general language.

In science terminology, borrowing covers two concepts: a) the term borrowed from another field and b) the term borrowed from another language. Hence, there is displacement of terms from one area to another and from one language to another. Considering the term as a linguistic expression of the concept, one can say that the process of borrowing concepts occurs between branches of science from different countries and between areas within a country. In the study of borrowings in general, attention has focused on identifying changes in their phonetic, morphological and semantic language they incur borrowing in relation to the language model talkie. A particular interest in the borrowing process regards the identification of the borrowing travel, i.e., a description of the way directly from the source to the receiving language or indirectly, from the source to intermediate language to language recipients, recorded in each phase transition corresponding changes undergone by the term in the three aspects mentioned above.

To follow the journey of a loan, i.e., to determine the source language, the intermediate term should be subjected to a multi-faceted analysis for the successful realization of which should be considered:

- A good knowledge of languages lending and borrowing, i.e., their structures, the study of the similarities and differences between them that synchronic level of diachronic;

- The study of social contacts, economic and cultural that has existed or exists between people sentence languages under consideration.

Analysis of terms borrowed should be done at three levels: a) phonetic level, where one should consider making language phonetic systems of the donor, the type of phoneme for each language and phonetic properties of the respective languages; b) morphological level, where it should be taken into consideration the fundamental change that characterizes the donor and receiver languages; c) semantic-conceptual level, where the term of the language model should be subject to conceptual analysis. In this context, particular attention should be paid to determining the content of the concepts expressed in terms of the relevant language. Conceptual convergence analysis is performed in order to compare the internal aspect of the relevant concepts, relying on common characteristics and differences. The conceptual analysis should be supported by the semantic aspect, which consists of comparing semantic structures borrowed those words which are used as a term. This is to better trace the journey of a borrowing as well as to determine its nearest intermediate language.

During the analysis of borrowings in order to determine the path of the transition from one language to another, there is a mutual process, firstly, a large number of terms that go from the source directly to the receiving language completely or partially preserving phonetics, morphological, conceptual indicators of the model, and secondly, some other terms go from the source to the receiving language indirectly, i.e., with the help of an intermediary language. In the process of borrowing, a concept can enter simultaneously in two different areas, for instance, there are two "economizer" terms used in thermo-technical terminology and in the auto-tractor terminology, these two terms express the same concept. Initially, this term is expressed in the English language, which is the source of this term. In the Albania technical terminology, this concept is expressed by two terms that belong to two intermediate languages, "ekonomaizer" in Russian, and Italian "ekonomizator" from "economizzatore."

During the analysis of borrowings in the lexicon of mechanics, there is a phenomenon that the same concept is borrowed from two or more terms from different languages in certain periods, such as "mufte-xhunte," "protecktor-

${ }^{2}$ Kostallari A. , Parimet themelore për hartimin e Fjalorit të gjuhës së sotme shqipe, Studime mbi leksikun dhe mbi formimin e fjalorëve në gjuhën shqipe, II, Tirane pp. 33.

${ }^{3}$ Leka F. Vëzhgime gjuhësore dhe leksikografike mbi termat në shkronjat N dhe S të FGJSSH (1980), Monografi, Tirane, pp. 48. 
batistradë," "atrecaturë-armature" and so forth. When using these borrowings in the Albanian language, while these borrowings entered from different languages regarding the same concept, they end up being used to differentiate between concepts, for instance, differentiated concepts in the field of thermal metal processing, in the concept "operation of thermal seasoned steel or light alloy processing" that is central to their uniform reheating at a temperature lower than the lower critical point and gradual cooling to obtain the best convergence were initially used two semantic borrowings Kalk or omission (taken from Russian) and riardhje (taken from French or Italian). But during their use within the vernacular of this field, these terms began to differentiate. "Riardhje" is used for the above concept and the term "leshim" is being used today to express the concept of "'riardhjes" process leading to the reduction or elimination of internal tensions".

Over time, borrowed terms are developed and standardized, so that in some cases there is a structural discrepancy between term and term borrowed model, or in other cases, the term model is replaced with a term in the language of the origin. For instance, "paracolpo" is a term entered from Italian, but "paracolpo" today in the Italian language is replaced by the term "paraurti," "spoliatrice" is replaced with "tornio a spogliaro," or the term derived from Italian "collo d'occa," is replaced with "albero motore" or "albero a gomiti." In general, a characteristic of borrowings in Albanian is their coexistence on equal terms with the language and this is explained by the ability of the Albanian language to assimilate borrowings by subjecting them to its system and microsystems. In this context, professor Kostallari has argued that the Albanian system has shown great ability of absorption for the elements borrowed, has profoundly changed them and given their features phonetic and grammatical faces consistent with Albanian, which characterizes all borrowings in the terminology of mechanics. ${ }^{4}$

Borrowings of this area are subject to the phonetic, morphological and lexical systems used in Albania and therefore change and develop according to it. This is observed in the phonetic aspect also in the morphological and lexical. For example, in morphology, "Albanian includes any loan easily in its paradigm ... Latin and Russian are also specific paradigms for some types of borrowings." ${ }^{5}$ The new borrowed term in Albanian is subject to its rules. Many borrowed words used today in the nursery have extended express different meanings. To mention a few: armature armoj - armim - I armaturar; filete - filetoj - filetim - I filetuar - vetëfiletues - pafiletuar - filetueshëm - filetueshmëri etc; godronim - godronoj - godronuar - godronues; ribatinë - ribatinoj - ribatinim - i ribatinuar; rimorkio - rimorkoj - rimorkim rimorkues - I rimorkuar; freze - frezoj - frezim - I frezuar - frezues; saldoj - saldim - I salduar - I saldueshem pasaldueshëm - I pasalduar- saldueshmëri etc. It should also be mentioned that the use of an extended version of the borrowed term occurs not only in the original language, but also in the receiving language. For instance, on the basis of the term "bokollë" derived from the Italian "boccola" there are formed and used words such as "bokollok," "bokollim," "I bokolluar," which overlook the original language.

In the lexical context, many borrowed words undergo a lexical internal development, i.e. a new meaning is formed which does not exist in the original language. For instance, the term "skorje" entered in the field of metallurgy and later on it was reappropriated for other uses. The semantic development of this word has been only within the Albanian language while overlooking its source. Borrowings in the mechanical field are divided into two main groups: the first group included all those borrowings mainly derived from Latin and Greek. This includes a number of borrowings arising from separate language but of an international character. Borrowings in this category include most of the terms borrowed in this field; we mention some of the terminology used in plastic and thermal processing of metals such autoclav, elektrode, fluid, galvanizim, grafite, granul, granulizim, granulator, granulometry, gjeneratoj, planimetrim, plastifikim, polimerizim, rekuperator, strukture, sferoidim, stabilitet, vullkanizator. Here it is worth mentioning a very rare phenomenon not observed in the process of internationalization of a term. Having expanded its territory in order to be used in the different communities of speakers, the term is not always retains its contents concept or semantic structure which it represents. In any event, it occurs that going in another language is used to designate a term such galvanization other concept in all languages used (fr. Galvanisation, it. Galvanizzazione etc.) expresses the concept "dress a metal object with a thin layer MetaLUN to protect it from oxidation". This concept in the English technical terminology uses the term "electroplating", while the term galvanization names one other concept "of a surface coating of zinc metal by some certain technological processes". The second group includes terms that are used in specific languages as in English, French, Italian, etc. and are Albanian terminology borrowed mechanics. In this paper, we focus on the analysis and detailed classification of borrowings of the group, which we have grouped starting from the way of penetration in the language, i.e. the path traversed during the borrowing process.

In this context, we distinguish two subgroups: a) direct loans, including all loans that entered the Albanian

${ }^{4}$ Kostallari A Gjuha letrare kombëtare shqipe dhe epoka jonë - 7-8 dhjetor 1984, Tirane pp 4.

${ }^{5}$ Leka F. Vëzhgime gjuhësore dhe leksikografike mbi termat në shkronjën N dhe S të FGJSSH, monografi, pp 47. 
language directly from the source. This subgroup includes terms such as, agregat, skopjoj, aliazh, atrecaturë, axhustator, balestër, batipal, bilancier, bokollë, bronzinë, buloneri, cilindër, cilindratë, cilindrim, cernierë, dadicek, dado, detal, detalizoj, ekonomizator, fashetë, fashoplastikë, fermo, filetë, filetaturë, filetatrice, friksion, galexhant, graso, grasator, guarnicion, indoto, kacavidë, kamerdare, kandele, kollodok, koperton, kurbalinjë, kushinetë, limatrice, madravidë, manikotë, marsh, maskarino, morsetë, morsë, motorino, muftë, parafango, parakolpo, permistop, pulexhë, punteri, punto, rakordim, ribatinë, ridoto, rondelë, saldator, saldim, saldatrice, separator, serbator, skapamento, spinot, spianim, spoliatrice, stokatrice, torneri, torno, trapano, tambur, volan, volant, xhioko, xhirant, xhuntë, smarilim and b) indirect borrowings that have entered in Albanian through another intermediary language.

From juxtaposing semantic structures of the donor language with the words of the borrowing language, we find that most of the technical borrowings have entered into Albanian with a shrinking semantic structure. By analyzing the change or the preservation of the semantic structure during the transition process, I construct the following classification:

1. borrowings entered into Albanian with a shrinking semantic structure, which includes alloy words, machinist, outrigger, buloneri, clip, shape, screw-thread, fillet, switch, washer, indoto, spark plug, karrel, crankshaft, madrevidë, collar, clamp, vise, saldatrice, fuel tank, exhaust, spinot, etc.,

2. b) the extension of semantic structure which includes the words armature, breakdown, welder, etc.

Whereas, according to the origin of the terms, we construct following classification:

1. Terms borrowed from the Italian language. Characteristic of the terms of this group is that every term entered in Albanian directly, unlike English or French words that may have penetrated into the Albanian technical terminology indirectly. Borrowings from the Italian language constitute the largest group of borrowings mechanics terminology. This is due mainly to the conditions and social contacts, economic, and cultural that existed between these two countries on the historical level. This refers to the open door policy before World War II, and Italian penetration in all areas of Albanian life of that period. A major influence in the introduction and spread of Italian terms comes from Italian professional schools, which became widespread in the main provinces of the country, in Shkodra, Berat, Korca, Gjirokastra. In these schools, where classes were held in Italian, Albanian students were familiarized for the first time with technical concepts.

2. Terms borrowed from the French, the group's borrowings entered into Albanian in two ways: directly such terms alloy cylinder, cilindrim, truck, etc kurbalinjë and indirectly, where can be mentioned terms: ambrazurë, bolt, FILIERE, godronim, gear, kalandër, mileage, jack, milling, exhaust, cock, prompter, Volan etc.

3. Terms borrowed from German into Albanian have penetrated indirectly where intermediate language has been Russian. Terms borrowed from German into the Albanian terminology used in mechanics are: buks, buksim, dam, shinning, shibar, shlicë, tronsel etc.

4. Terms borrowed from English, the group's borrowings have penetrated into the Albanian language i.e. indirectly through an intermediate language which was mostly Russian. In this group, the terminology used in mechanics includes the terms such as: antifreeze, bypass, economizer etc.

\section{Conclusions}

First, before starting the analysis of each borrowing, the linguistic and terminological viewpoints ought to be taken into consideration. According to the linguistic perspective, the word and its content are studied on the basis of expanding or narrowing its semantic structure in the transition from one language to another. Whereas, according to the terminological standpoint, the term and concept are studied based on conceptual compliance rates.

Secondly, on the basis of the classification made by the semantic-conceptual analysis, the largest number of borrowings included in the special vocabulary of mechanics comprise borrowings from Italian, which is due mainly to the conditions and social contacts, economic and cultural that existed between these two countries on the historical level.

Thirdly, the classification made on the basis of conceptual analysis, this lexical borrowings are mainly characterized by internal convergence. However, there are also cases with no internal convergence, which suggests that there was complete replacement of the content of the borrowed term from one language to another.

Finally, borrowings that have entered this special lexicon are distributed in all sub-areas of mechanics, in different proportions with largest number in the areas of machinery deltas and auto-tractors. 


\section{References}

Cabej E. (1980). Aleksander Xhuvani dhe gjuhesia historike shqiptare. Studime filologjike 1

J. Thomai (1988). Rreth shtresimit historik te leksikut te shqipes sipas studimeve te prof Cabejit, Studime Filologjike 3

Haugen E. (1950). The analysis of linguistic borrowing. Language 26 210-231

Kostallari A. (1984). Gjuha letrare kombëtare shqipe dhe epoka jonë - 7-8 dhjetor

Kostallari A. (1972). Mbi disa vecori strukturore e funksionale te gjuhes letrare shqipe te kohes sone. Studime mbi leksikun dhe mbi formimin e fjaleve ne gjuhen shqipe I, 7-61

Kostallari A. Parimet themelore për hartimin e Fjalorit të gjuhës së sotme shqipe, Studime mbi leksikun dhe mbi formimin e fjalorëve në gjuhën shqipe, II, Tirane 33

Lafe E. (1972). Terminologjia e matematikes dhe e mekanikes teorike. Studime mbi leksikun dhe mbi formimin e fjaleve ne gjuhen shqipe II, 315-318

Lloshi Xh. (1972). Terminologjia e elektroteknikes. Studime mbi leksikun dhe mbi formimin e fjaleve ne gjuhen shqipe II, 325-328

Leka F. (1980). Vëzhgime gjuhësore dhe leksikografike mbi termat në shkronjat N dhe S të FGJSSH .Tirane 
